\title{
ANÁLISIS DE LA CADENA DEL VALOR DE AMARANTO EN MÉXICO
}

\section{ANALYSIS OF THE AMARANTH VALUE CHAIN IN MÉXICO}

\author{
Alma V. Ayala-Garay ${ }^{1}$, Eduardo Espitia-Rangel ${ }^{1}$, Patricia Rivas-Valencia ${ }^{1}$, \\ Guillermina Martínez-Trejo ${ }^{1}$, Gustavo Almaguer-Vargas ${ }^{* 2}$
}

\begin{abstract}
${ }^{1}$ Campo Experimental Valle de México, Km. 13.5 Carretera Los Reyes Texcoco, Coatlinchán, Texcoco estado de México, México. 56250. (ayala.alma@inifap.gob.mx) (espitia.eduardo@ inifap.gob.mx) (rivas.patricia@inifap.gob.mx) ${ }^{2}$ Departamento de Fitotecnia. Universidad Autónoma Chapingo. Km. 38.5 Carretera México Texcoco, Chapingo, México. 56230. (almaguervargas@hotmail.com)
\end{abstract}

\section{RESUMEN}

El objetivo de este estudio fue realizar un análisis de la cadena de valor del amaranto, considerando a los actores, sus relaciones y funciones, así como los factores que afectan su competitividad. Se utilizó la técnica de paneles y encuestas en campo. Todo esto se realizó de octubre a noviembre de 2013, con la participación de expertos de los estados de Puebla, Morelos, Oaxaca, Hidalgo, San Luis Potosí, Edo. de México y Tlaxcala. Se encontró que existe poca vinculación entre la investigación y los productores; faltan políticas que impulsen la integración de la cadena y la organización de la misma; existe una limitada promoción comercial en mercados internacionales; la comercialización del amaranto es el eslabón más vulnerable. Los productores venden su producción a la industria transformadora, en tiendas y en los supermercados locales, y un alto porcentaje de las ventas de la industria procesadora está destinada a atender programas de Gobierno. La estructuración entre la provisión de insumos y el mercado final no es la más adecuada. Las relaciones de poder son jerárquicas, pocos actores compradores tienen el poder, la información y su relación con sus proveedores es comercial. No existen vínculos horizontales a nivel de productores, lo cual no permite mejorar la capacidad de negociación y la organización.

Palabras clave: actores, cadena de valor, relaciones y vínculos.

\section{INTRODUCCIÓN}

$\mathrm{E}$ l amaranto (Amaranthus spp) es una planta cultivada y utilizada en México desde hace más de 4000 años, con una gran tradición por su uso en aspectos religiosos, alimentación y ofrendas en

* Autor responsable * Author for correspondence.

Recibido: noviembre, 2014. Aprobado: diciembre, 2015.

Publicado como ARTÍCULO en ASyD 13: 87-104. 2016.

\section{Abstract}

The objective of this study was to perform an analysis of the amaranth value chain, taking into account the actors, relationships and functions, as well as the factors that affect its competitiveness. The technique of panels and field surveys was used. This was all carried out from October to November, 2013, with the participation of experts from the states of Puebla, Morelos, Oaxaca, Hidalgo, San Luis Potosí, Estado de México and Tlaxcala. It was found that there is little connection between research and the producers; there is a lack of policies that foster the integration and organization of the chain; there is limited commercial promotion in international markets; amaranth marketing is the weakest connection. The producers sell their product to the transformation industry, in stores and local supermarkets, and a high percentage of the sales of the processing industry are destined to addressing government programs. The structuring between the supply of inputs and the final market is not the most adequate. Power relations are hierarchal, few purchasing actors have power or information, and their relationship with suppliers is commercial. There are no horizontal connections at the level of producers, which does not allow improving the ability for negotiation and the organization.

Key words: actors, value chain, relationships and connections.

\section{INTRODUCTION}

A maranth (Amaranthus spp) is a plant that is cultivated and used in México since more than 4000 years ago, with a great tradition because of its use in religious aspects, in the diet and for offerings in Pre-Hispanic cultures (Casas et al, 2001; Sauer, 1976). Its importance lies in its high nutritional value, both in the amount and in the quality of the protein, better than cereals of 
las culturas prehispánicas (Casas et al, 2001; Sauer, 1976). Su importancia radica en su alto valor nutritivo, tanto en cantidad como en calidad de proteína, superando a cereales de uso común como el trigo (Triticum aestivum), el arroz (Oryza sativa), la avena (Avena sativa) y el maíz (Zea mays) (Morales et al., 2009). De acuerdo con Barba de la Rosa et al. (2009), el amaranto produce semillas con niveles elevados de proteína total, así como del aminoácido lisina, generalmente deficiente en otros cereales (Belton y Taylor, 2002), por lo que puede colocarse en diferentes nichos importantes de mercado.

La FAO (1997) cataloga al amaranto como un cultivo con la misma cantidad de nutrientes que la soya. Barrales et al. (2010) mencionan que es un cultivo prometedor que puede cultivarse en condiciones de temporal, con tolerancia a sequías y un rendimiento mayor o similar a otros cultivos en igualdad de circunstancias. Lo anterior hace del cultivo una alternativa de producción y consumo adecuada para regiones marginadas del país.

En los últimos años la superficie sembrada y el volumen de producción de amaranto en México registraron durante el periodo de 1982 a 2010, tasas de crecimiento media anual (TCMA) de 8.17 y $15.34 \%$ (SIACON-SAGARPA, 2012).

En los años 1997,1999 y 2001 se tuvieron las máximas superficies cultivadas con áreas superiores a las tres mil hectáreas. De 2004 a 2007 se estabilizó la superficie a un nivel ligeramente superior a las dos mil hectáreas; entre 2008 y 2010 la superficie alcanzó nuevamente más de tres mil hectáreas, con un promedio de 3047 . Una situación similar ocurrió con la producción, donde se tuvieron incrementos variables, con un salto a partir de 1995 y un máximo histórico en 2001, con la misma tendencia a la estabilización de 2004 a 2007 de tres mil toneladas y un promedio de 4075 toneladas. El porcentaje de participación del valor de la producción del amaranto en el valor de la producción agrícola total, creció a una tasa media anual de $8.17 \%$ durante el mismo periodo (SIACON-SAGARPA, 2012)

Sin embargo, en México el amaranto no ocupa un lugar dentro de los productos que son considerados básicos y estratégicos (Art. 70 Ley de Desarrollo Rural Sustentable ${ }^{3}$ ). Contrariamente a su importancia como parte de la identidad de las culturas prehispánicas, de su origen, y principalmente de la opción que presenta como actividad económica common use such as wheat (Triticum aestivum), rice (Oryza sativa), oats (Avena sativa) and maize (Zea mays) (Morales et al., 2009). According to Barba de la Rosa et al. (2009), amaranth produces seeds with high levels of total protein, as well as the amino acid lysine, generally deficient in other cereals (Belton and Taylor, 2002), so it can be placed in different important market niches.

FAO (1997) catalogues amaranth as a crop with the same amount of nutrients than soy. Barrales et al. (2010) mention that it is a promising crop that can be cultivated under rainfed conditions, with tolerance to drought and a higher or similar yield than other crops under the same conditions. This makes the crop an alternative for adequate production and consumption in marginalized regions of the country.

In recent years the surface sown and the volume of amaranth production in México showed mean annual growth rates (MAGR) of 8.17 and $15.34 \%$ during the period of 1982 to 2010 (SIACONSAGARPA, 2012).

The maximum surfaces cultivated were during the years 1997, 1999 and 2001, with areas of more than three thousand hectares. From 2004 to 2007, the surface stabilized at a level slightly above two thousand hectares; between 2008 and 2010 the surface reached more than three thousand hectares again, with an average of 3047. A similar situation occurred with production, where there were variable increases, with a jump starting in 1995 and a historical maximum in 2001, with the same tendency towards stabilization from 2004 to 2007 of three thousand tons and an average of 4075 tons. The percentage of participation of the value of amaranth production in the total agricultural production value grew at a mean annual rate of $8.17 \%$ during the same period (SIACON- SAGARPA, 2012).

However, in México, amaranth does not occupy a place among the products that are considered basic and strategic (Article 70 of the Sustainable Rural Development $\left.\mathrm{Law}^{3}\right)$. Contrary to its importance as part of the identity of Pre-Hispanic cultures, of its origin and primarily of the option that it presents as an economic activity for peasant agriculture, and its nutritional characteristics, the amaranth value chain has great challenges to overcome from the viewpoint of competitiveness, particularly because the crop is developed in small communities under conditions of scarcity, not only of natural resources such as 
para la agricultura campesina y sus características nutricionales, la cadena de valor de amaranto, desde el punto de vista de competitividad, tiene grandes retos que superar, sobre todo porque el cultivo se desarrolla en pequeñas comunidades en condiciones de escasez, no sólo de recursos naturales como lo es el agua, sino también de tecnología en la producción y transformación en las regiones donde se produce (De la $\mathrm{O}$ Olán et al., 2012) y la falta de financiamiento para acceder a tecnología disponible (Ayala et al., 2012).

En aspectos de comercialización y venta, los productores no están organizados, lo que es uno de los aspectos más vulnerables de la cadena, puesto que $80 \%$ de los productores vende a intermediarios, quienes deciden el precio a inicios de la temporada de cosecha y lo incrementan o disminuyen dependiendo de la oferta y la demanda (Ayala et al., 2014).

Los grandes transformadores realizan todo el proceso de industrialización del grano, para elaborar una gran diversidad de productos.

Por estas razones, se puede concluir que la deficiente integración de la cadena de valor del amaranto, incluyendo sus procesos de comercialización, la aplicación de deficientes prácticas culturales, la ausencia de economías de escala, y la poca organización para la venta de sus productos, aunado a la competencia con cultivos que se pueden mecanizar más fácilmente así como el bajo precio de venta del producto, ha repercutido en un reducido ingreso de los productores; de $\$ 7075.56$ por hectárea (Ayala et al., 2014), y es necesario analizar de manera más sistemática dicha cadena para proponer alternativas que permitan el mejoramiento de su competitividad.

Por lo anterior, el objetivo del presente estudio fue desarrollar un análisis integral de la cadena de valor del amaranto, considerando a los actores, sus relaciones y funciones, así como los factores que afectan la competitividad de la cadena, para establecer alternativas que permitan contribuir a revertir las limitaciones que se tienen para mejorar el ingreso de los productores.

Por cadena de valor se hace referencia a la manera en que un conjunto de actores se relacionan en función de un producto específico, para agregar o aumentar su valor a lo largo de los diferentes eslabones, desde su etapa de producción hasta el consumo, incluyendo la comercialización, el mercado y la distribución (Acosta, 2006). Porter (1985) define una cadena de valor como el conjunto de actividades water, but also of technology in the production and transformation in regions where it is produced (De la O Olán et al., 2012), and because of the lack of financing to gain access to the technology available (Ayala et al., 2012).

In terms of marketing and sales, producers are not organized, which is one of the most vulnerable aspects of the chain, since $80 \%$ of producers sell to intermediaries, who decide the price at the beginning of the harvest season and increase it or decrease it depending on the offer and demand (Ayala et al., 2014).

The large transformers carry out the whole process of grain industrialization, in order to elaborate a great diversity of products.

For these reasons, it can be concluded that the deficient integration of the amaranth value chain, including its marketing processes, the application of deficient cultural practices, the absence of economies of scale, the scarce organization for the sale of their products, in addition to the competition against crops that can be more easily mechanized and the low sale price of the product, have had an impact on producers' small income, of $\$ 7075.56$ per hectare (Ayala et al., 2014); it is necessary to analyze this chain more systematically in order to suggest alternatives that allow improving its competitiveness.

Therefore, the objective of this study was to develop an integral analysis of the amaranth value chain, considering the actors, their relationships and functions, as well as the factors that affect the chain's competitiveness, in order to establish alternatives that allow helping to revert the limitations present to increase the producers' income.

Value chain refers to the way in which a set of actors are related in function of a specific product, in order to add or increase its value throughout the different links, from the stage of production to the consumption, including commercialization, market and distribution (Acosta, 2006). Porter (1985) defines a value chain as the set of activities that an organization must develop in order to take a product from the producer to the consumer within a business system.

Value chains ease the creation of productive alliances, allowing the most efficient use of the resources; they highlight the role of distribution and marketing as key factors for a greater competitiveness, they ease the flow of information between actors, 
que una organización debe desarrollar para llevar un producto desde el productor hasta el consumidor en un sistema de negocios.

Las cadenas de valor facilitan la creación de alianzas productivas, permitiendo el uso más eficiente de los recursos; resaltan el papel de la distribución y el mercadeo como factores claves de una mayor competitividad, facilitan el flujo de información entre los actores, ayudan al desarrollo de soluciones de manera conjunta con la identificación de problemas y cuellos de botella a lo largo de la cadena y, por último, permiten analizar de manera independiente y conjunta cada eslabón de la misma (Peña et al., 2008).

En un sentido más amplio, una cadena de valor se refiere a los vínculos comerciales y flujos de insumos, productos, información, recursos financieros, logística, comercialización y otros servicios entre proveedores de insumos, procesadoras, exportadores, minoristas y otros agentes económicos que participan en el suministro de productos y servicios a los consumidores finales. Una cadena de valor se entiende como una alianza o red estratégica entre un número de organizaciones independientes dentro de una cadena productiva (CIAT, 2007).

La importancia del estudio de la cadena de valor del amaranto radica en la identificación de las limitaciones, tanto en la actividad productiva misma, como en las estrategias interinstitucionales que intervienen dentro de esta cadena. Sobre estas debilidades se plantean acciones a seguir, para dar alternativas a los problemas, generando eficiencias en la cadena, $y$, finalmente, ventajas competitivas.

\section{Metodología}

\section{Descomposición de factores del crecimiento de la producción de amaranto en el entorno nacional}

Para determinar de manera precisa el grado de influencia que han tenido factores como el rendimiento, indicador de innovación y la superficie cosechada o un efecto combinado en el crecimiento de la producción, se utilizó la ecuación de Venezian y Gamble (1969), modificada por Contreras (2000), y se tomaron los datos de SIACON-SAGARPA (2012):

$P_{t}=Y_{0}\left(A_{t}-A_{0}\right)+A_{o}\left(Y_{t}-Y_{0}\right)+\left(A_{t}-A_{0}\right)\left(Y_{t}-Y_{0}\right)$

dónde: $P_{t}=$ Incremento total de la producción para el periodo de análisis; $Y_{0}\left(A_{t}-A_{0}\right)=$ Cuantifica la contribución they help develop solutions in a joint manner with the identification of problems and bottlenecks throughout the chain, and lastly, they allow analyzing each link in the chain independently and jointly (Peña et al., 2008).

In a broader sense, a value chain refers to the commercial connections and flows of inputs, products, information, financial resources, logistics, marketing and other services between suppliers of inputs, processing plants, exporters, retailers, and other economic agents who participate in the supply of products and services to the final consumers. A value chain is understood as an alliance or strategic network between a number of independent organizations within a productive chain (CIAT, 2007).

The importance of the study of the amaranth value chain lies in the identification of limitations, both in the productive activity itself and in the interinstitutional strategies that intervene within the chain. Regarding these weaknesses, we suggest actions to be followed, to offer alternatives to the problems, which could generate efficiencies in the chain, and, ultimately, competitive advantages.

\section{Methodology}

\section{Breakdown of growth factors in amaranth production in the national scope}

To determine precisely the degree of influence that factors such as yield, an innovation indicator and the surface harvested have had, or a combined effect in the growth of production, the Venezian and Gamble equation (1969) was used, modified by Contreras (2000) and data from SIACON-SAGARPA (2012) were used:

$P_{t}=Y_{0}\left(A_{t}-A_{0}\right)+A_{o}\left(Y_{t}-Y_{0}\right)+\left(A_{t}-A_{0}\right)\left(Y_{t}-Y_{o}\right)$

where: $P=$ Total increase of the production for the period analyzed; $Y_{0}\left(A_{t}-A_{0}\right)=$ Quantifies the contribution of the surface; $A_{0}\left(Y_{t}-Y_{0}\right)=$ Quantifies the contribution of the yield; $\left(A_{t} A_{0}\right)\left(Y_{t}-Y_{0}\right)=$ Quantifies the combined effect of surface and yield; $A_{0}=$ Average surface harvested initial $(1980=222.50 \mathrm{ha}) ; A_{t}=$ Average surface harvested final $(2010=3047.33 \mathrm{ha}) ; Y_{0}=$ Average national yield initial $\left(1980=0.41\right.$, in $\left.\mathrm{t} \mathrm{ha}^{-1}\right) ; Y_{t}=$ Average yield final $\left(2010=1.34 \mathrm{tha}^{-1}\right)$. 
de la superficie; $A_{0}\left(Y_{t}-Y_{0}\right)=$ Cuantifica la contribución del rendimiento; $\left(A_{t} A_{0}\right)\left(Y_{t}-Y o\right)=$ Cuantifica el efecto combinado de superficie y rendimiento; $A_{0}=$ Superficie promedio cosechada inicial $(1980=222.50$ ha $)$; $A_{t}=$ Superficie promedio cosechada final $(2010=3047.33$ ha); $Y_{0}=$ Rendimiento promedio nacional inicial $\left(1980=0.41\right.$, en $\left.\mathrm{t} \mathrm{ha}^{-1}\right) ; Y_{t}=$ Rendimiento promedio final $\left(2010=1.34 \mathrm{tha}^{-1}\right)$.

Si el incremento total de la producción para el periodo $1982-2010$ es igual a $100 \%$, es posible determinar la proporción que corresponde a cada factor, para evaluar si el crecimiento ha sido intensivo o extensivo. El crecimiento extensivo consiste en el aumento de la producción vía el incremento de la superficie cosechada, situación que remite a la obsolescencia tecnológica. El crecimiento intensivo se relaciona con el aumento en la producción vía incremento en rendimiento, hecho que remite a un mayor nivel tecnológico. Un crecimiento combinado remite a incremento de superficie y rendimiento por igual (Zarazúa et al. 2009).

\section{Paneles de trabajo}

Para construir las características de la cadena de valor del amaranto se utilizó la técnica de paneles. Los paneles se conformaron por grupos de expertos de los estados de México, Puebla, Morelos, Oaxaca, Hidalgo, San Luis Potosí y Tlaxcala, para lograr la caracterización del sistema de producción, su nivel tecnológico y escalas dentro de un rango de capacidad productiva. En estos grupos participaron conocedores de la cadena. Esto se realizó durante el mes de octubre de 2013.

La primera sesión de trabajo en campo consistió en una orientación sobre los fundamentos, principios y conceptos alrededor de la metodología de cadenas de valor en la que los participantes definieron los primeros lineamientos en relación con el análisis de la cadena y los factores que definen la competitividad.

Utilizando un proceso de construcción de consenso, en cada panel se estableció un diálogo con los expertos, con el fin de recabar la información relacionada desde la producción, así como de parámetros técnicos y sistemas de comercialización para un año base. De tal manera que la información fue acordada en consenso por los panelistas. Posteriormente se recibió retroalimentación y se construyeron estrategias
If the total increase in production for the 19822010 period is equal to $100 \%$, it is possible to determine the proportion that corresponds to each factor, to evaluate if the yield has been intensive or extensive. The extensive growth consists in the increase in production through the increase of the surface harvested, situation that refers to technological obsolescence. The intensive growth relates to the increase in production via yield increase, fact that refers to a higher technological level. A combined growth refers to an increase in surface and yield equally (Zarazúa et al. 2009).

\section{Work panels}

The technique of panels was used to build the characteristics of the amaranth value chain. The panels were made up of groups of experts from the states of Estado de México, Puebla, Morelos, Oaxaca, Hidalgo, San Luis Potosí and Tlaxcala, to achieve the characterization of the production system, its technological level, and the scales within a range of productive capacity. People who know the chain participated in these panels. They were carried out during the month of October, 2013.

The first working session in the field consisted in training about the foundations, principles and concepts around the methodology of value chains, during which the participants defined the first guidelines with regard to the analysis of the chain and the factors that define competitiveness.

Using a process of consensus building, in each panel a dialogue was established with the experts, with the aim of collecting information related from the production, as well as the technical parameters and commercialization systems for one base year. Therefore, the information was agreed upon under consensus of the panelists. Later, feedback was received and strategies and recommendations were developed. It took place during November, 2013, the attendees were representatives from the value chain in several states, such as input suppliers, producers' representatives from different zones, two of the main transformers in the amaranth industry, representatives from SAGARPA, INIFAP, and nongovernmental organizations.

Once the information was captured and processed, and with the aim of ensuring the validity 
y recomendaciones. Se realizó en el mes de noviembre de 2013, los asistentes fueron representantes de la cadena de valor de varios Estados, como proveedores de insumos, representantes productores de diferentes zonas, dos de los principales transformadores en la industria del amaranto, representantes de SAGARPA, INIFAP y Organizaciones No Gubernamentales.

Una vez capturada y procesada la información y con el fin de asegurar la validez y representatividad de los datos obtenidos, los resultados fueron validados por los panelistas.

La validación se realizó mediante un proceso de consenso, en el cual se convocó nuevamente a los participantes del panel original. En esta etapa, los resultados se presentaron con la intención de verificar que la información era completa y correcta, además de que se comprobó si esta información reflejaba la situación de la cadena de valor. Del mismo modo, se verificó que los panelistas estuvieran de acuerdo en que el análisis prospectivo reflejara adecuadamente sus expectativas sobre las tendencias del sector. El proceso de validación es un requisito indispensable para la publicación y difusión de resultados (ZavalaPineda et al., 2012).

La cadena de valor de amaranto se modeló con la información dada por el grupo de expertos participantes en dos paneles.

\section{Encuestas en campo}

Se realizaron 17 encuestas dirigidas a informantes clave de la cadena, los cuales forman parte del sistema productor, o bien del Consejo de Productores de los estados de México (3), Puebla (3), Morelos (3), Oaxaca (3), Hidalgo (1), San Luis Potosí (3) y Tlaxcala (1). A nivel de industriales y mercado se realizaron cinco encuestas: San Luis Potosí (3), Hidalgo (1) y Tlaxcala (1).

Las encuestas se conformaron con preguntas cualitativas, que se transformaron usando una escala de 1 a 5 para un análisis cuantitativo. Las preguntas realizadas fueron con la finalidad de generar las variables descritas a continuación.

\section{Mapa conceptual de la cadena del valor de amaranto}

Para obtener el mapa de la cadena de valor, se analizaron los siguientes niveles: and representativeness of the data obtained, the results were validated by the panelists.

The validation was performed through a consensus process, where the participants from the original panel were called again. In this stage, the results were presented with the intention of verifying whether the information was complete and correct, in addition to verifying if this information reflected the situation of the value chain. Likewise, it was verified that the panelists agreed in that the prospective analysis adequately reflected their expectations regarding the sector's trends. The validation process is an indispensable requirement for publishing and divulging results (Zavala-Pineda et al., 2012).

The amaranth value chain was modelled with the information given by the group of experts participating in two panels.

\section{Field surveys}

Seventeen surveys were carried out with key informants in the chain, which are part of the production system or else of the Producers' Council in the states of Estado de México (3), Puebla (3), Morelos (3), Oaxaca (3), Hidalgo (1), San Luis Potosí (3) and Tlaxcala (1). At the level of industrialists and markets, five surveys were performed: San Luis Potosí (3), Hidalgo (1) and Tlaxcala (1).

The surveys were made up of qualitative questions that were transformed using a scale of 1 to 5 for qualitative analysis. The questions asked were with the aim of generating the variables described next.

\section{Conceptual map of the amaranth value chain}

In order to obtain a map of the value chain, the following levels were analyzed:

- Actors and functions. The agents and functions that each carry out were identified, through the questions asked and the search for information in the Amaranth Product System.

- Relationships and horizontal connections. The interactions between agents or actors were described, as well as their level of organization.

- Primary information from the national market. Important information from the national consumption market was analyzed, and about the attributes of the products offered. 
- Actores y funciones. Se identificaron los agentes y las funciones que cada uno de ellos realiza, a través de las preguntas realizadas y búsqueda de información del Sistema Producto Amaranto.

- Relaciones y vínculos horizontales. Se describieron las interacciones entre los agentes o actores y su nivel de organización.

- Información primaria del mercado nacional. Se analizó información relevante del mercado nacional, de consumo y de atributos de los productos que se ofertan.

- Servicios críticos de apoyo. Se recabó información relacionada con servicios financieros relacionados con el acceso a créditos.

- Servicios de asistencia técnica. Se presentó información relativa al servicio de asesoría técnica a los productores.

- Servicios de gestión de calidad. Se buscaron instrumentos de carácter regulatorio para transformación de productos.

- Inteligencia comercial. Se hizo un análisis con el propósito de conocer sobre la cultura de consumo, calidad del amaranto y sus propiedades.

- Logística y almacenamiento. Se buscó identificar los actores que participan en este rubro.

\section{Resultados y Discusión}

\section{Descomposición de factores del crecimiento de la producción del amaranto en el entorno nacional}

El crecimiento de la producción de amaranto es determinado por la combinación del incremento de la superficie y el rendimiento en un $66.12 \%$ (Cuadro 1), es decir, este crecimiento se ha dado por la interacción entre ambos factores, no es sólo por el aumento en superficie o en rendimiento, sino una combinación de ambos.

Por otro lado, el incremento del rendimiento por hectárea entre 1982 y 2010, aumentó a una tasa de crecimiento media anual (TCMA) de $4.36 \%$, mientras que el de la producción fue de $15.34 \%$.

En relación con el incremento de la productividad, su crecimiento está en función de la adopción de innovaciones tecnológicas, que son recomendadas según las características de las zonas de producción (Estrada et al., 2006). Sin embargo, la adopción de estos paquetes tecnológicos, ha sido casi nula. De acuerdo con
- Critical support services. Information related to financial services was gathered, related to access to credit.

- Technical support services. Information related to the service of technical support for producers was presented.

- Quality management services. Instruments of a regulatory nature were sought, for the transformation of products.

- Commercial intelligence. An analysis was carried out with the purpose of understanding the culture of consumption, quality of amaranth and its properties.

- Logistics and storage. It was sought to identify the actors that participate in this area.

\section{Results AND Discussion}

\section{Decomposition of growth factors of amaranth production in the national scope}

The growth of amaranth production is determined by the combination of the increase in surface and the yield in $66.12 \%$ (Table 1); that is, this growth has occurred because of the interaction between both factors, not only because of the increase in surface or yield, but rather from a combination of both.

On the other hand, the increase in yield per hectare between 1982 and 2010 increased at a mean annual growth rate (MAGR) of $4.36 \%$, while that of production at $15.34 \%$.

With regard to the increase in productivity, its growth is in function of the adoption of technological innovations, which are recommended according to the characteristics of the production zones (Estrada

Cuadro 1. Participación de factores en el incremento de la producción de amaranto.

Table 1. Participation of factors in the increase of amaranth production.

\begin{tabular}{lrcrr}
\hline & Superficie & Rendimiento & $\begin{array}{c}\text { Interacción } \\
\text { superficie- } \\
\text { rendimiento }\end{array}$ & Total \\
\hline $\begin{array}{l}\text { Valor } \\
\text { obtenido }\end{array}$ & 1144.54 & 207.95 & 2640.06 & 3992.55 \\
Porcentaje & $28.67 \%$ & $5.21 \%$ & $66.12 \%$ & $100 \%$ \\
\hline
\end{tabular}

Fuente: elaboración propia con datos de SAGARPA-SIACON, 2012. Source: authors' elaboration with data from SAGARPASIACON, 2012. 
Muñoz et al. (2007), en la adopción de tecnologías intervienen múltiples factores, pero uno de los más importantes es la participación del extensionista capacitado, que conozca redes de innovación y esta situación prácticamente no se cumple.

\section{Mapa de la cadena de valor}

Se generó el mapa de la cadena de valor de amaranto (Figura 1), para mostrar a los actores sus funciones, servicios de apoyo y relaciones en el flujo del producto desde su producción al mercado final.

Actores y funciones. El flujo de la cadena se inicia con la agroindustria proveedora de insumos principalmente para la producción primaria; continúa con el acopio de la producción; luego la transformación del grano, y concluye con la venta (al mayoreo y menudeo). A la izquierda del gráfico están representadas las principales funciones en el flujo de productos, desde su elaboración hasta el mercado final.

Los productores menores (menos de $10 \mathrm{ha}$ ) cumplen varias funciones en la cadena y por tanto están representados con un rectángulo que cubre la producción de materia prima, el acopio y el procesamiento artesanal de productos a base de amaranto (Figura 1). La diferenciación según el tamaño de productores se da porque aquellos con menos de 10 ha venden su producción a acopiadores locales, los que a su vez venden su producción a procesadores artesanales locales. Estos a su vez venden su producción al por mayor en la central de abasto, o al por menor en pequeñas tiendas, supermercados locales, tiendas naturistas, y en algunos casos a la industria. De acuerdo con los comentarios de los panelistas, los productores que poseen más de 10 ha normalmente venden su producción a la gran industria transformadora.

Relaciones y vínculos horizontales. En la Figura 1 se pueden apreciar las diferentes relaciones y flujos. Por ejemplo, en el flujo de proveedores de insumos al mercado, no hay diversidad entre la provisión de insumos y el mercado final; no obstante, existen comerciantes informales a quienes venden los proveedores sus productos y que no agregan valor en la cadena, ya que son sólo comerciantes.

Las relaciones de poder en la cadena son jerárquicas; pocos compradores que tienen el poder, la información, dejando la relación con sus proveedores a nivel comercial, a excepción del caso de la Empresa San Miguel, que de acuerdo con productores clave et al., 2006). However, the adoption of these technological packages has been almost non-existent. According to Muñoz et al. (2007), multiple factors intervene in the adoption of technologies, but one of the most important ones is the participation of a trained extension agent, who is knowledgeable about innovation networks, and this situation is practically unfulfilled.

\section{Map of the value chain}

The map of the amaranth value chain (Figure 1) was generated to show the actors, their functions, support services and relationships in the flow of the product from its production to the final market.

Actors and functions. The flow of the chain begins with the agroindustry that supplies inputs, mainly for primary production; it continues with the stockpiling of production; then, grain transformation, and concludes with the sale (wholesale and retail). To the left of the image the main functions in the product flow are represented, from their elaboration to the final market.

Minor producers (less than $10 \mathrm{ha}$ ) fulfill several functions in the chain and, therefore, are represented with a rectangle that covers the production of raw material, the stockpiling and the artisanal processing of products made with amaranth (Figure 1). The differentiation based on the size of producers happens because those with less than 10 ha sell their production to local collectors, who in turn sell their production to local artisanal processers. These, in turn, sell their production wholesale to the central market, or retail in small stores, local supermarkets, health food stores, and in some cases to the industry. According to comments by panelists, producers who own more than 10 ha normally sell their production to the large transforming industry.

Horizontal relationships and connections. Figure 1 shows the different relationships and flows. For example, in the flow of input suppliers to the market, there is no diversity between the supply of inputs and the final market; nevertheless, there are informal traders to whom suppliers sell their products and do not add any value to the chain, since they are only dealers.

The power relations in the chain are hierarchical; few buyers who have the power, the information, leaving the relationship with their suppliers at a 


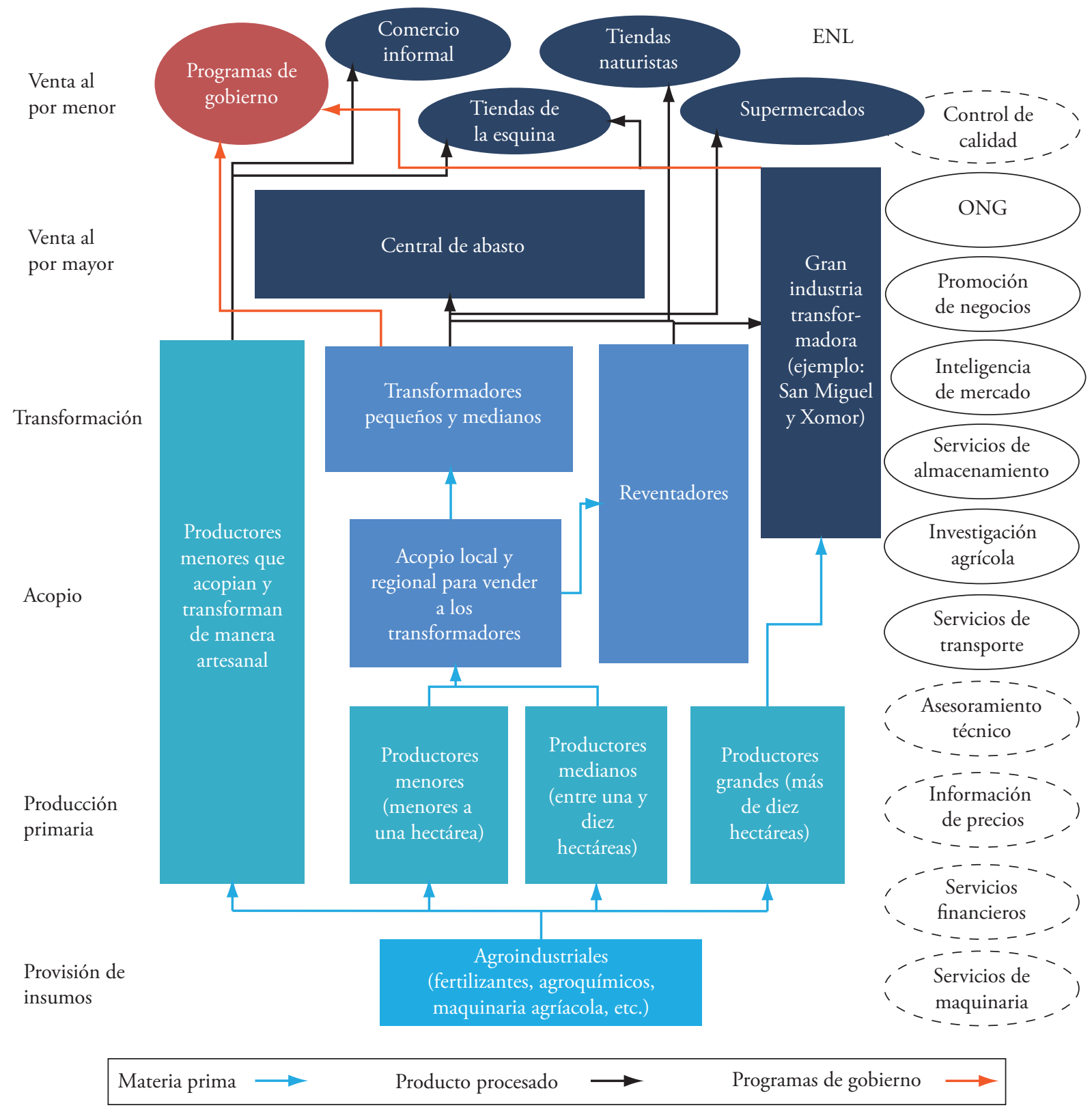

Figura 1. Mapa de la cadena de valor del amaranto en México.

Figure 1. Map of the amaranth value chain in México.

encuestados, tiene un serio compromiso social; es un referente de responsabilidad, su involucramiento equitativo con sus miembros ha determinado que todo un pueblo mejore su calidad de vida alrededor de ésta empresa procesadora.

Es importante resaltar que varios de los liderazgos reconocidos dentro de la cadena de amaranto en México tienen la visión de poder desarrollarla bajo lineamientos de Economía Solidaria, aprovechando la ventana de oportunidad que existe ante la ausencia commercial level, except in the case of Empresa San Miguel, which according to key producers surveyed have a serious social commitment; it is an example of responsibility, and its equitable involvement with members has determined that a whole town improves its quality of life around this processing company.

It is important to highlight that several of the leaderships recognized within the amaranth chain in México have the vision of being able to develop it under guidelines of Solidary Economy, taking 
de un actor corporativo preponderante que imponga las lógicas mercantilistas, de acuerdo con varios actores entrevistados.

Vínculos horizontales. De acuerdo con la información analizada de las encuestas y paneles, no existen mayores ejemplos referentes de vínculos horizontales a nivel de productores. No se pudo identificar en este trabajo una cultura de asociatividad de productores que les permita mejorar su capacidad de negociación y modificar las relaciones de poder.

A nivel de industriales se han desarrollado vínculos horizontales para la elaboración de la normativa de calidad mexicana de grano y reventado de Amaranto. Por otro lado los actores tienen representación de vínculos horizontales en una mesa de planificación de Sistema Producto en los Estados de Morelos, Tlaxcala, Ciudad de México y San Luis de Potosí. Oaxaca no es reconocido como Sistema Producto, pero sí participa en la mesa de diálogo a nivel nacional; Puebla no participa y se pretende que esta iniciativa pueda tener en un futuro un alcance de Sistema Producto Nacional, que defina el plan estratégico rector de la cadena de amaranto.

De los actores encuestados en la cadena y panelistas 59 \% mencionaron que existe una baja a muy baja participación de los miembros en la cadena de valor para la toma de decisiones, lo que es una limitante porque el nivel de participación también está ligado a la voluntad de inversión para mejoramiento de la cadena.

Es interesante que $76 \%$ de los encuestados mencionaron que existe un bajo a muy bajo nivel de cooperación entre actores, las principales razones para la falta de cooperación aparecen en el siguiente gráfico. Asímismo en cuanto al grado de asociatividad de los productores $77 \%$ mencionaron no pertenecer formalmente a ningún tipo de asociación. Esto limita las relaciones de poder, especialmente en cuanto al volumen y capacidad de negociación de los productores y es una importante limitación en la cadena (Figura 2).

Información primaria del mercado nacional. Por tipo de proceso en México se producen $79.9 \%$ de productos a base de grano reventado, $17.2 \%$ a base de harina y $2.9 \%$ a base de extruido (Espitia $e t$ al., 2012).

Escalante (2011), menciona que "el grano reventado" se refiere a la semilla que se coloca en comales de barro o metálicos calentados con fuego de leña advantage of the window of opportunity that there is in face of the absence of a preponderant corporate actor that would impose the commercial logic, according to several actors interviewed.

Horizontal connections. Based on the information analyzed from the surveys and panels, there are no relevant examples in terms of horizontal connections at the level of producers. A culture of association among producers, which would allow them to improve their capacity for negotiation and to modify the power relations, could not be identified in this study.

At the level of industrialists, horizontal connections have been developed to elaborate the Mexican quality regulations for the grain and popping of amaranth. On the other hand, the actors have a representation of horizontal connections in a planning board for the Product System in the states of Morelos, Tlaxcala, Mexico City and San Luis de Potosí. Oaxaca is not recognized as Product System, but does participate in the dialogue table at the national level; Puebla does not participate and we pretend for this initiative to have a reach for the National Product System in the future, to define the strategic reagent plan for the amaranth chain.

Of the actors surveyed in the chain and the panelists, $59 \%$ mentioned that there is a low to very low participation of the members in the value chain for decision-making, which is a limiting factor because the level of participation is also linked to the willingness to invest to improve the chain.

It is interesting that $76 \%$ of the people surveyed mentioned that there is a low to very low level of cooperation between actors, and the main reasons for the lack of cooperation appear in the following figure. Likewise, in terms of the degree of association of producers, $77 \%$ mentioned that they do not belong formally to any type of association. This limits the power relations, especially with regard to the volume and the producers' ability to negotiate, and is an important limiting factor in the chain (Figure 2).

Primary information from the national market. Because of the type of process in México, $79.9 \%$ of the products are based on popped grain, $17.2 \%$ based on flour, and $2.9 \%$ based on extruded (Espitia et al., 2012).

Escalante (2011) mentions that the "popped grain" refers to the seed that is placed on clay or metal pans that are heated up with firewood or gas so 
Grado de cooperación entre actores

Razones para la falta de cooperación

Grado de asociatividad

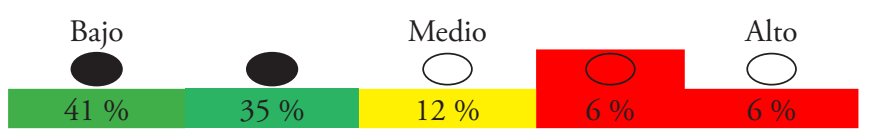

Falta de interés, egoísmo, hermetismo, apatía, de organización, individualismo, competencia interna, corrupción, cooperación no productiva, falta de comunicación.

Figura 2. Cooperación entre actores en la cadena de valor de amaranto.

Figure 2. Cooperation between actors in the amaranth value chain.

o de gas para que se infle; ya reventado, se enfría el grano expandido, después se criba para separar el grano que no se expandió, se envase en bolsas para almacenarlo, y se vende como cereal o se utiliza como insumo de otros productos.

En México 58.9\% de los productos se consumen en forma de alegrías (dulce tradicional), que está elaborado con miel, azúcar o piloncillo y algunos otros ingredientes. Entre los productos de mayor aceptación en el mercado se encuentran palanquetas simples $(24.3 \%)$, obleas $(7.9 \%)$, cubiertos $(6.3 \%)$, y otros productos (Espitia et al., 2012).

De acuerdo con los comentarios de los panelistas, el mayor riesgo en la cadena está del lado de los productores, pues la producción depende de las condiciones climáticas, ya que las lluvias al momento de la cosecha pueden hacer perder la producción; no obstante, la utilidad se incrementa conforme se avanza en los eslabones de la cadena.

A nivel de mercado el equipo de encuestadores cuantificó que $65 \%$ de las personas que compran son las que consumen. Los consumidores mencionaron que los principales usos de los productos a base de amaranto son polvo para mezclar con agua, suplemento de alimentos, granola o para consumo directo. Los principales productos que consumen son alegrías, palanquetas, granolas, cereales, reventados y obleas. Los consumidores declararon que los atributos de los productos que determinan su decisión de compra son el nivel nutricional, sabor, precio y presentación, según los porcentajes que aparecen en el cuadro. Esta información es importante para orientar esfuerzos comunicacionales para generar cultura de consumo de los productos (Figura 3). that it becomes inflated; once popped, the expanded grain is left to cool, then it is sifted to separate the grain that did not expand, it is poured into bags to be stored, and it is sold as cereal or used as input for other products.

In México, $58.9 \%$ of the products are consumed as alegrias (traditional sweets), made with honey, sugar or molasses, and other ingredients. Among the products of greater acceptance in the market, there are simple palanquetas $(24.3 \%)$, wafers (7.9\%), covered (6.3\%), and other products (Espitia et al., 2012).

According to comments from panelists, the greatest risk in the chain is on the side of producers, since the production depends on the weather conditions, since the rains at the time of the harvest can make them lose the production; however, the profitability is increased as you move forward in the chain's links.

At the level of market, the team of interviewers quantified that $65 \%$ of the people who purchase are the ones who consume. Consumers mentioned that the main uses of the amaranth-based products are powder to mix with water, food supplements, granola, or for direct consumption. The main products consumed are alegrias, palanquetas, granolas, cereals, popped grains, and wafers. The consumers declared that the attributes of the products that determine their purchasing decision are the nutritional level, the flavor, price and presentation, according to the percentages that are shown in the table. This information is important to guide the communication efforts to generate a culture of consumption of the products (Figure 3 ). 
Persona que compra es la misma que consume

Principales usos del producto

Principales productos de consumo

Principales atributos de los productos

Figura 3. Especificidades de atributos del producto.

Figure 3. Specificities of the product's attributes.

Servicios críticos de apoyo. La información primaria levantada mostró algunos servicios que son críticos en la cadena de valor de amaranto. A continuación se presentan los resultados de las encuestas.

Servicios financieros. En las sesiones de trabajo y en las encuestas levantadas, se mencionó al financiamiento como una limitante para mejorar tecnología o capital de trabajo. El $65 \%$ de encuestados mencionaron tener de bajo a muy bajo acceso al crédito. Por otro lado, existen una serie de entidades que ofrecen crédito para productores agrícolas, mismas que aparecen en la Figura 4. No obstante, aparentemente como el amaranto no está declarado como un cultivo estratégico las prioridades de financiamiento van a otros cultivos. El $47 \%$ mencionaron que, o no son sujetos de crédito, o el costo de capital es de alto a muy alto.

Servicios de asistencia técnica. La dificultad de acceso a la asistencia técnica es también una limitante que en general mencionaron tanto en las sesiones de trabajo como en las encuestas. El $94 \%$ de productores indicaron que aunque existen entidades que ofrecen asistencia técnica a nivel rural, ellos no tienen acceso a asistencia de calidad, pues la asistencia técnica que existe se enfoca a otros cultivos declarados como prioritarios (Figura 5).
Critical support services. The primary information gathered showed some services that are critical in the amaranth value chain. Next, the results from the surveys are presented.

Financial services. In the working sessions and in the surveys applied, financing was mentioned as a limiting factor to improve technology or working capital. Of those surveyed, $65 \%$ mentioned they have low to very low access to credit. On the other hand, there are a series of entities that offer credit to agricultural producers, which are shown in Figure 4. However, apparently since amaranth is not declared as a strategic crop, other crops are the priority for financing; $47 \%$ mentioned that either they are not candidates for credit, or the capital cost is too high.

Technical assistance services. The difficulty in access to technical assistance is also a limiting factor that is generally mentioned, both in the working sessions and in the surveys. $94 \%$ of the producers indicated that although there are entities that offer technical assistance at the rural level, they do not have access to quality assistance, because the technical assistance available is focused on other crops declared as priority (Figure 5).

Quality management services. Differences in the quality and innocuousness of many of the amaranth-
Acceso a crédito

Costo de capital

Principales instituciones

Financieras que ofrecen crédito para productores de amaranto

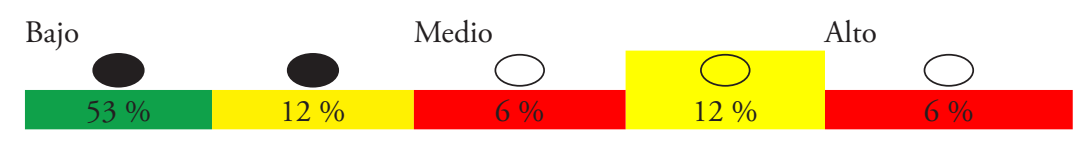

Bajo

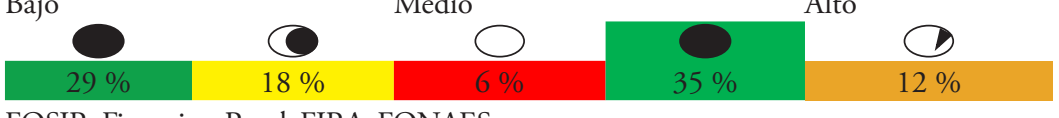

FOSIR, Financiera Rural, FIRA, FONAES, PRONAFIM, Programa Nacional de Financiamiento al Microempresario, FIMAGO

Figura 4. Resultados de servicios financieros.

Figure 4. Results of financial services. 
Servicios de gestión de calidad. Se identificaron diferencias en la calidad e inocuidad de muchos de los productos a base de amaranto, especialmente de los que se producen a nivel artesanal, lo cual requiere una regulación. Según Escobedo et al. (2012), en un muestreo realizado de productos a base de amaranto, $65 \%$ cumplían con estándares de excelente calidad como los establecidos en las normas mexicanas aplicables [NMX-114-SCFI-2009 Grano de amaranto. Especificaciones de calidad y métodos de ensayo y PROY NMX-116-SCFI-2010 Grano reventado de amaranto (Amaranthus spp.) para uso y consumo humano].

De acuerdo con los resultados de las encuestas y sesiones de trabajo, $47 \%$ de actores afirman que existe un alto a muy alto cumplimiento de estándares de calidad; y $41 \%$ de las personas mencionó que existen altos incentivos para mejorar la calidad en la cadena. El $82 \%$ de los productores indica no disponer de infraestructura para mejorar la calidad. Un bajo porcentaje indicó disponer de equipo para trillado, centro de acopio y logística apropiada para asegurar una gestión apropiada de calidad.

Inteligencia comercial. El propósito de los participantes en las sesiones de trabajo en cuanto a mercado en común, era generar cultura de consumo de calidad de amaranto, y ligar el consumo a las propiedades nutritivas y de identidad cultural. No obstante, una deficiencia identificada en la cadena de amaranto es el conocimiento sobre el perfil del consumidor final y sobre la gestión de mercadeo. Se necesita complementar el presente análisis con una investigación de mercado y de mercadeo que permita identificar segmentos, canales potenciales, y de acuerdo con esa información, encontrar la estrategia adecuada para comunicar y posicionar en la mente de los consumidores el mensaje de mercadeo apropiado.

Logística y almacenamiento. Sobre los servicios de logística y almacenamiento, no se identificaron actores que ofrezcan estos servicios, de acuerdo con las encuestas y las reuniones que se llevaron al cabo.

\section{Discusión}

En el presente estudio se reconoce que la cadena de valor es una herramienta de gestión que permite realizar un análisis interno, a través de la desagregación en sus principales actividades generadoras de valor en amaranto.
Acceso asistencia técnica

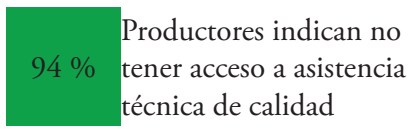

Entidades que ofrecen asistencia técnica a nivel rural

Universidades y organizaciones campesinas, asociadas civiles

Universidades, INIFAP provee de semilla de

Investigación agrícola amaranto pero no dispone de recursos para asistencia técnica

Figura 5. Resultados de asistencia técnica. Figure 5. Results of technical assistance.

based products were identified, particularly in those produced at the artisanal level, which is something that requires regulation. According to Escobedo et al. (2012), in a sample made of amaranth-based products, $65 \%$ complied with standards of excellence in quality such as those established in the applicable Mexican norms [NMX-114-SCFI-2009. Amaranth grain. Specificities of quality and assay methods; and PROY NMX-116-SCFI-2010. Popped amaranth grain (Amaranthus spp.) for human use and consumption].

According to the results from the surveys and working sessions, $47 \%$ of the actors state that there is a high to very high compliance to the quality standards, and $41 \%$ of people mentioned that there are high incentives to improve the quality in the chain. $82 \%$ of the producers indicate they do not have the infrastructure to improve the quality. A low percentage indicated they have the equipment for threshing, the gathering center and appropriate logistics to ensure an adequate quality management.

Commercial intelligence. The purpose of participants in the working sessions with regard to the market in common was to generate a consumption culture of amaranth quality, and to connect consumption to the nutritional properties and of cultural identity. However, a deficiency identified in the amaranth chain is the knowledge about the final consumer's profile, and about marketing management. This analysis needs to be complemented with market and marketing research that allows identifying segments, potential channels, 
Las más destacadas limitaciones en la cadena de valor de amaranto son la poca o nula vinculación entre investigación y las necesidades de los productores. Por parte de las instituciones de investigación falta presupuesto para realizar investigación básica y aplicada. Sin embargo, de acuerdo con Santacruz (2011), diversos gobiernos estatales han ofrecido discursivamente apoyos para el impulso de la producción de amaranto, pero sus ofrecimientos no se han concretado y los productores consideran que, de existir esos apoyos, se podría ampliar hasta 25 mil hectáreas la superficie sembrada.

El eslabón de comercialización no está regularizado, faltan políticas que impulsen la integración de la cadena y la organización de la misma; derivado de esto, existe limitada promoción comercial en mercados internacionales de los productos derivados del amaranto, por lo que se debe de impulsar su comercialización, ya que de acuerdo con Ayala et al. (2014), este eslabón es de los más vulnerables en la cadena.

Dentro de las oportunidades estratégicas para la industria, Cortés et al. (2009) mencionan que se debe fomentar el consumo del amaranto, aprovechar la identidad como parte de la cultura mexicana y alternativa para generar una cultura de consumo de productos a base de amaranto de calidad, y generar los incentivos a través de un sistema producto a nivel nacional, ya que de acuerdo con Ayala et al. (2012) se encuentran también innumerables beneficios documentados para su aprovechamiento integral; dado que es un grano versátil para la transformación e industrialización. Es importante la generación del Plan estratégico rector para toda la cadena, que le dé representatividad y que pueda hacer las gestiones ante el Gobierno para lograr que se declare al amaranto como producto estratégico, y generar los incentivos entre los miembros y priorizar los siguientes pasos a corto mediano y largo plazo para revertir las limitaciones en oportunidades.

Derivado del análisis de los paneles y resultado de las encuestas a agentes clave, se mencionan las siguientes estrategias:

Productividad. Los impactos reales y potenciales a nivel de producción de amaranto se darán por la adopción de tecnologías que permitan mejorar la rentabilidad (Muñoz et al., 2007), tales como acceso a las nuevas variedades de semilla mejorada; manejo técnico adecuado del cultivo en cuanto a la densidad, nutrición, sanidad; y en particular a tecnologías en la and based on this information, finding the adequate strategy to communicate and position in the mind of consumers the appropriate marketing message.

Logistics and storage. Regarding the services of logistics and storage, no actors were identified who offer these services, according to the surveys and meetings that took place.

\section{Discussion}

In this study it is recognized that the value chain is a management tool that allows performing an internal analysis through the disaggregation into its main activities, which generate value in amaranth.

The limitations that stand out most in the amaranth value chain are the scarce or non-existent connection between research and the needs of the producers. From research institutions, there is a lack of budget to carry out basic and applied research. However, according to Santacruz (2011), various state governments have offered supports, in discourse, for the promotion of amaranth production, although their offerings have not been fulfilled and the producers consider that, if those supports had existed, the surface sown could be expanded to up to 25 thousand hectares.

The marketing link is not regulated, there is a lack of policies that foster the chain's integration and organization; derived from this, there is limited commercial promotion in international markets of the products derived from amaranth, so their marketing should be promoted, since according to Ayala et al. (2014), this link is one of the weakest in the chain.

Within the strategic opportunities for the industry, Cortés et al. (2009) mention that amaranth consumption should be fostered, taking advantage of identity as a part of the Mexican and alternative culture, to generate a consumption culture of quality amaranth-based products, and to create the incentives through a product system at the national level; according to Ayala et al. (2012), there are also countless benefits documented for its integral exploitation, since it is a versatile grain for transformation and industrialization. Generating a guiding strategic plan for the whole chain is important, to give it representativeness, to carry out the negotiations before the government in order to achieve for amaranth to be declared a 
producción, como riego en donde exista disponibilidad de agua.

Generar cultura de consumo. Se requiere una estrategia bien planificada, planteada en el Plan estratégico rector para toda la cadena, que incluya campańas de educación al cliente, para persuadir a los consumidores potenciales del valor nutricional, de identidad del amaranto, y nuevas prácticas de mercadeo.

Entorno nacional para negocios. Reformas o nuevas políticas públicas, regulaciones, normativas, para eliminar los obstáculos al aumento de la competitividad de la industria. Por ejemplo, incentivos para mejorar el equipamiento para mejora de calidad, cambio en las regulaciones de normativas de registro de productos de cada Estado, declaración del amaranto como producto estratégico, promoción y campańas públicas contra la desnutrición y el hambre. Subsidios agrícolas, sobre todo de acceso a factores de producción.

Mejoramiento de relaciones. Definir una ruta lógica de siguientes pasos y reuniones periódicas de sistema producto. Favorecer el mejoramiento de vínculos verticales $\mathrm{u}$ horizontales que permitan una mayor eficiencia (la creación de economías de escala, reducir costos de transacción, etcétera) En las entrevistas, los participantes mencionaron una iniciativa para declarar el día nacional de amaranto.

Flujo de información. Se requiere mejorar el flujo de información o de servicios para mejorar la calidad de los productos y reducir costos.

\section{Conclusiones}

Existe poca o nula vinculación entre investigadores y productores.

Los productores con más de 10 hectáreas normalmente venden su producción a la industria transformadora, al por mayor en tiendas y en los supermercados locales, así como al por menor; no obstante, un buen porcentaje de las ventas de la industria procesadora está destinada a atender programas de Gobierno, siendo éste el principal motor de la cadena.

La estructuración entre la provisión de insumos y el mercado final no es la más adecuada; no obstante existen comerciantes informales a quienes venden los proveedores sus productos y que no agregan valor en la cadena, son solamente comerciantes.

Las relaciones de poder en la cadena son jerárquicas: pocos actores compradores que tienen el poder, strategic product, and to generate the incentives among members and to prioritize the next steps in the mid and long term to revert the limitations in opportunities.

Derived from the analysis of the panels and as a result from the surveys with key agents, the following strategies can be mentioned:

Productivity. The real and potential impacts at the level of amaranth production will take place as a result of the adoption of technologies that allow improving profitability (Muñoz et al., 2007), such as access to new varieties of improved seed; adequate technical management of the crop in terms of density, nutrition, health; and, particularly, technologies in production, such as irrigation where there is water availability.

Generating a culture of consumption. A wellplanned strategy is required, set out in the strategic guiding plan for the whole chain, which should include campaigns for client education, to persuade potential consumers of the nutritional value, amaranth identity, and new marketing practices.

National environment for business. Reforms or new public policies, regulations, norms, to eliminate the obstacles to the increase in the industry's competitiveness must take place. For example, incentives to improve the outfitting to improve quality; a change in the regulations for norms for product registry from each state; declaring amaranth as a strategic product; promotion and public campaigns against malnutrition and hunger. Agricultural subsidies, especially access to production factors.

Improving relationships. Defining a logical route for the next steps and periodical meetings of the product system. Favoring the improvement of vertical or horizontal connections that allow a greater efficiency (the creation of economies of scale, reducing transaction costs, etc.). In the interviews, participants mentioned an initiative to declare a national amaranth's day.

Information flow. The information flow must be improved, or of services to improve the quality of products and to reduce costs.

\section{Conclusions}

There is a scarce or non-existent connection between researchers and producers. 
la información, y su relación con sus proveedores es básicamente comercial.

El eslabón de comercialización no está regularizado, faltan políticas que impulsen la integración de la cadena y la organización de la misma. Por ello, existe limitada promoción comercial en los mercados nacionales e internacionales.

Es importante resaltar que varios de los liderazgos reconocidos dentro de la cadena de amaranto en México tienen la visión de poder consolidar la cadena de amaranto bajo lineamientos de economía solidaria.

No existen vínculos horizontales a nivel de productores, lo cual impide mejorar la capacidad de negociación, la organización y modificar las relaciones de poder.

Los participantes mencionaron una alternativa para solventar el riesgo que corre el productor, mediante un seguro agrícola, que podría proponerse por parte del Sistema Producto Nacional a SAGARPA o a las entidades competentes.

Existe de baja a muy baja participación de los miembros en la cadena de valor para la toma de decisiones.

Existe dificultad de financiamiento como una limitación para mejorar tecnología o capital de trabajo. La dificultad de acceso a la asistencia técnica es también una limitante que en general se mencionaron tanto en las sesiones de trabajo como en las encuestas.

Sobre los servicios de logística y almacenamiento, no se identificaron actores que ofrezcan estos servicios, de acuerdo con las encuestas y las reuniones que se llevaron al cabo.

\section{Agradecimientos}

Este trabajo fue financiado por Puente a la Salud Comunitaria, ubicado en privada de Magnolias \#109, Col. Reforma C.P. 68050 Oaxaca, Oax, México pete.noll@gmail.com, agradecemos su apoyo, en especial a Pete Noll.

\section{Notas}

${ }^{3}$ En el artículo 70 de la Ley de Desarrollo Rural Sustentable se menciona qué productos son considerados como básicos y estratégicos (maíz, caña de azúcar, frijol, trigo, arroz, sorgo, café, huevo, leche, carne de
Producers with more than 10 hectares normally sell their production to the transforming industry, wholesale in stores and in local supermarkets, as well as retail; however, a good percentage of the sales by the processing industry is destined to serving government programs, since the latter is the main motor of the chain.

The structuring between input provision and the final market is not the most adequate; nevertheless, there are informal traders who sell the suppliers their products and who do not add value to the chain, they are only dealers.

The power relations in the chain are hierarchical; few purchasing actors have the power, the information, and their relationship with their providers is basically commercial.

The marketing link is not regulated, and there is a lack of policies to foster the chain's integration and organization. Therefore, there is limited commercial promotion in the national and international markets.

It is important to highlight that several of the leaderships recognized within the amaranth chain in México have the vision of being able to consolidate the amaranth chain under guidelines of solidary economy.

There are no horizontal links at the level of producers, which impedes improving the ability to negotiate, to organize, and to modify the relations of power.

The participants mentioned an alternative to address the risk that the producer takes, through agricultural insurance, which could be proposed by the National Product System to SAGARPA or the competent authorities.

There is low to very low participation of the members of the value chain for decision-making.

There is difficulty for financing as a limitation to improve technology or working capital. The difficulty in access to technical assistance is also a limiting factor, which in general is mentioned both in the working sessions and in the surveys.

Regarding the services of logistics and storage, no actors were identified who offer these services, according to the surveys and the meetings that were held.

\section{AKNOWLedgements}

This study was financed by Puente a la Salud Comunitaria, located at Magnolias \#109, Col. 
bovinos, porcinos, aves, pescado) $\bullet$ Article 70 of the Sustainable Rural Development Law describes which products are considered as basic and strategic (maize, sugar cane, bean, wheat, rice, sorghum, coffee, eggs, milk, beef, pork, poultry, fish).

\section{Literatura Citada}

Acosta, L. 2006. Agrocadenas de Valor y Alianzas Productivas: Herramientas de apoyo a la agricultura familiar en el contexto de la globalización. Santiago de Chile: Oficina regional de la FAO para América Latina y el Caribe.

Ayala, G. A. V., L. D. Escobedo, E. L. Cortés, y R. E. Espitia. 2012. El cultivo de amaranto en México, descripción de la cadena, implicaciones y retos, INIFAP Campo Experimental Valle de México.

Ayala, G. A. V., E. L. Cortes, V. P. Rivas, M. De La O Olán, L. D. Escobedo, y R. E. Espitia. 2014. La rentabilidad del cultivo amaranto en la región centro de México, INIFAP Campo Experimental Valle de México. Universidad Autónoma del Estado de México. Ciencia ergo-sum, 21-1:47-54.

Barba de la Rosa, A. P., I. S. Fomsgaard, B. Laursen, A. G. Mortensen, J. L. Olvera-Martínez, C. Silva-Sánchez, A. Mendoza-Herrera, A. De León-Rodríguez, and J. González-Castañeda. 2009. Amaranth (Amaranthus hypochondriacus) as an alternative crop for sustainble food production: phenolic acids and flavonoids with potential impact on its nutraceutical quality. Journal of Cereal Science 49:117-121.

Barrales, D. J. S., E. Barrales, y E. Barrales. 2010. Amaranto. Recomendaciones para su producción. Universidad Autónoma Chapingo, Plaza y Valdés y Fundación Produce Tlaxcala. México D.F. 166 p.

Belton, P., and J. R. N. Taylor. 2002. Pseudocereals and less common cereals. Springer-Verlag. Berlin, Heideberg, Alemania. $261 \mathrm{p}$.

Casas, A., A. Valiente-Banuet, J. L. Viveros, J. Caballero, L. Cortés, P. Dávila, R. Lira, and I. Rodríguez. 2001. Plant resources of the Tehuacán-Cuicatlán Valley, Mexico. Economic Botany, 55(1): 129-166.

CIAT (Centro Internacional de Agricultura Tropical). 2007. La cadena de Carne Bovina en Costa Rica: Identificación de Temas críticos para impulsar su Modernización, Eficiencia y Competitividad. 75 p.

Contreras, C. J. M. 2000. La competitividad de las exportaciones mexicanas de aguacate: un análisis cuantitativo. Reporte de investigación No. 46, Centro de Investigaciones Económicas, Sociales y Tecnológicas de la Agroindustria y la Agricultura Mundial (CIESTAM). Universidad Autónoma Chapingo (UACh), México. 42 p.

Cortés, E. L., E. Espitia, P. Rivas-Valencia, y J. M. HernándezCasillas. 2009. Diagnóstico socioeconómico de la producción de amaranto en Valles Altos. VI Reunión Nacional de Innovación Agrícola. León, Guanajuato, México. 327 p.

De la O Olán, M., R. E. Espitia, G. A. V. Ayala, C. J. M. Hernández, V. J. L. Arellano, y H. V. C. Ruiz. 2012. Caracterización morfológica en germoplasma para grano de amaranto (Amaranthus spp.). In: Espitia, R. E., S. C. Mapes, L. D. Es-
Reforma C.P. 68050 Oaxaca, Oax, México, pete. noll@gmail.com; we thank their support, especially Pete Noll's.

- End of the English version -

cobedo, M. De la O Olán, Rivas, P. Valencia, G. Martínez Trejo, L. Cortés Espinoza, J. M. Hernández Casillas 2010. Amaranto: Ciencia y Tecnología. INIFAP, Centro de Investigación Regional Centro, Celaya, Guanajuato, México. pp: 165-181.

Escalante, E. M. C. 2011. Rescate y revaloración del cultivo del amaranto. Instituto Interamericano de Cooperación para la Agricultura (IICA). 2010, Fondo CONACYT-SAGARPA, COFUPRO e IICA. 91 p.

Espitia, R. E., S. C. Mapes, L. D. Escobedo, M. De la O Olán, V. P. Rivas, E. L. Martínez Cortés, y C. J. M. Hernández. 2012. Amaranto: Ciencia y Tecnología. INIFAP, Centro de Investigación Regional Centro, Celaya, Guanajuato, México. 368 p.

Estrada, L. Á., C. S. Sahagún, M. J. S. Muruaga, C. J. M. Hernández, y V. M. L. Vargas. 2006. Guía para la producción de amaranto en el Distrito Federal. Folleto para Productores No. 16. INIFAP. SAGARPA. México.

FAO (Food and Agriculture Organization). 1997. El cultivo del amaranto (Amaranthus spp.): producción, mejoramiento genético y utilización. http://www.rlc.fao.org/es/agricultura/ produ/cdrom/contenido/libro01/Cap1.htm

Morales, G. J. C., M. N. Vázquez, y C. R. Bressani. 2009. El amaranto: Características físicas, químicas, toxicológicas y funcionales y aporte nutricio. Instituto Nacional de Ciencias Médicas y Nutrición Salvador Zubirán. 1era. edición México, D.F.

Muñoz, R. M., A. C. Reyes, Á. J. Aguilar, R. M. Rendón, M. J. G. García, y G. A. Espejel. 2007. Innovación: motor de la competitividad agroalimentaria. Políticas y Estrategias para que en México ocurra. CIESTAAM/PIAI. Universidad Autónoma Chapingo. México.

Peña, Y., A. P. Nieto, y R. F. Díaz. 2008. Cadenas De Valor: Un Enfoque Para Las Agrocadenas. Equidad \& Desarrollo, Norteamérica. Disponible En: <Http://Revistas.Lasalle.Edu. Co/Index.Php/Ed/Article/View/279>. Fecha De Acceso: 25 Jun. 2014.

Porter, M. 1985. The Value Chain and Competitive Advantage: Creating and sustaining superior performance. New York: Free Press.

Santacruz De León, E.E. 2011. La producción de Amaranto en Tlaxcala, México. In: Observatorio de la Economía Latinoamericana, No 148. México, D.F. Texto completo en http:// www.eumed.net/cursecon/ecolat/mx/2011/.

Sauer, J. D. 1976. Grain amaranth. Evolution in crop plants. N.W. Simmonds (ed) London, Longman. pp: 4-7.

SIACON-SAGARPA (Sistema de información agroalimentaria de consulta. Secretaría de Agricultura, Ganadería, Desarrollo Rural, Pesca y Alimentación). 2012. Sistema de información agroalimentaria de consulta. México, D. F.

Venezian L., E., and W. K. Gamble. 1969. Chapter 6. Factors influencing Mexican agriculture development. The agricultural development of Mexico. Its structure and growth since 1950. In: Frederic K. A. Praeger, Publisher. New York, Washington. London. pp: 92-120. 
Zarazúa, J., A. Solleiro, J. L. Altamirano, R. Castañón, y R. Rendón. 2009. Esquemas de innovación tecnológica y su transferencia en las agroempresas frutícolas del estado de Michoacán. Revista Estudios Sociales 17(34): 37-71.

Zavala-Pineda, M. J., J. M. Salas-González, J. A. Leos-Rodríguez, y L. M. Sagarnaga-Villegas. 2012. Construcción de unidades representativas de producción porcina y análisis de su viabilidad económica en el período 2009-2018. Agrociencia, 46(7), 731-743. Recuperado en 24 de junio de 2014, de http://www. scielo.org. $\mathrm{mx} /$ scielo.php?script=sci_arttext\&pid=S1405$31952012000700008 \& \operatorname{lng}=$ es\&tlng=es. 